Article

\title{
Solvent Engineering for Intermediates Phase, All-Ambient-Air-Processed in Organic-Inorganic Hybrid Perovskite Solar Cells
}

\author{
Lei Shi ${ }^{\circ}$, Huiying Hao *, Jingjing Dong *, Tingting Zhong, Chen Zhang, Jiabin Hao, Jie Xing and \\ Hao Liu \\ School of Science, China University of Geosciences, Beijing 100083, China \\ * Correspondence: huiyinghaoL@cugb.edu.cn (H.H.); jjdong@cugb.edu.cn (J.D.)
}

Received: 18 May 2019; Accepted: 5 June 2019; Published: 26 June 2019

check for updates

\begin{abstract}
Intermediate phase is considered an important aspect to deeply understand the crystallization procedure in the growth of high-quality perovskite layers by an anti-solvent technique. However, the moisture influence on the intermediate phase formation is not clear in air conditions as yet. In this work, pure $\left(\mathrm{FA}_{0.2} \mathrm{MA}_{1.8}\right) \mathrm{Pb}_{3} \mathrm{X}_{8}$ (DMSO-DMF) intermediate phase was obtained in as-prepared perovskite film by spin-coating the precursor of co-solvent (DMSO and DMF) in an ambient air (RH20-30\%). Moreover, the appropriate quantity of ethyl acetate $\left(\mathrm{C}_{4} \mathrm{H}_{8} \mathrm{O}_{2}, \mathrm{EA}\right)$ also controls the formation of pure intermediate phase. The uniform and homogeneous perovskite film was obtained after annealing this intermediate film. Therefore, the best power conversion efficiency (PCE) of perovskite solar cells (PSCs) is $16.24 \%$ with an average PCE of $15.53 \%$, of which almost $86 \%$ of its initial PCE was preserved after 30 days in air conditions. Besides, the steady-state output efficiency ups to $15.38 \%$ under continuous illumination. In addition, the PCE of large area device $\left(100 \mathrm{~mm}^{2}\right)$ reaches $11.11 \%$ with a little hysteresis effect. This work would give an orientation for PSCs production at the commercial level, which could lower the cost of fabricating the high efficiency PSCs.
\end{abstract}

Keywords: perovskite solar cells; intermediate phase; air condition; solvent engineering

\section{Introduction}

Organic-inorganic hybrid perovskite solar cells (PSCs) have revolutionized the field of photovoltaics, with rapid progress in power conversion efficiency (PCE) from 3.8\% in 2009 [1] to the present record of $24.2 \%$ [2]. Great progress has been made for different device configurations, including the classic $n-i-p$ structures and inverted $\mathrm{p}-\mathrm{i}-\mathrm{n}$ structures according to the sequence of thin film deposition [3]. Whatever the configuration is, the high performance of PSCs can be attributed to excellent photoelectric properties of perovskite layer such as high absorption, long carrier diffusion lengths, and appropriate band gap [4,5]. Various synthesis approaches to obtain high quality perovskite layer have been reported, including sequential deposition of inorganic and organic components, single-step spin-coating, thermal evaporation, and vapor-assisted method [6-8]. The single-step spin-coating method is generally used due to the ease of processing. To obtain the uniform and pinhole-free perovskite layer, anti-solvent treatment has been developed using solvents such as toluene and chlorobenzene during the spin-coating process [9-11]. The anti-solvent is miscible in the precursor solvents, but is not insoluble in the perovskite component. In this way, all precursor salts are dissolved in a mixed solvent, then spin-coated after the precursor solution is fully dissolved, with anti-solvent dropped on the top of the film during the spinning process. The precursor solution plays an important role in the excellent performance of PSCs. Generally, N,N-dimethylformamide (DMF), dimethylsulphoxide (DMSO) and $\gamma$-butyrolactone (GBL) or their mixture are used as solvents 
for precursor salts [12-14]. Jeon et al. suggested DMSO, and GBL (3:7 volume ratio) as a co-solvents for the precursors [15], which presented favorable surface coverage and smooth film with the toluene treatment, because the intermediate phase of $\mathrm{CH}_{3} \mathrm{NH}_{3} \mathrm{I}-\mathrm{PbI}_{2}-\mathrm{DMSO}$ restricts the fast reaction between $\mathrm{CH}_{3} \mathrm{NH}_{3} \mathrm{I}$ and $\mathrm{PbI}_{2}$ during the rapid solvent evaporation in the spin-coating process. After that, Park et al. suggested combining the Lewis base DMSO, the iodide( $\left.\mathrm{I}^{-}\right)$of $\mathrm{CH}_{3} \mathrm{NH}_{3} \mathrm{I}$, and Lewis acid $\mathrm{PbI}_{2}$ to form an $\mathrm{CH}_{3} \mathrm{NH}_{3} \mathrm{I}-\mathrm{PbI}_{2}-\mathrm{DMSO}$ intermediate phase via the adduct approach [16]. They demonstrated the formation of a 1:1:1 adduct of $\mathrm{CH}_{3} \mathrm{NH}_{3} \mathrm{I}-\mathrm{PbI}_{2}$-DMSO film by spin-coating a DMF precursor solution containing equimolar $\mathrm{CH}_{3} \mathrm{NH}_{3} \mathrm{I}, \mathrm{PbI}_{2}$, and $\mathrm{DMSO}$, followed by anti-solvent diethyl ether drop-casting. In addition, Rong et al. used a mixed DMSO/DMF (3:1 volume ratio) co-solvent and toluene as the anti-solvent, identifying the intermediate phase structure as $\mathrm{MA}_{2} \mathrm{~Pb}_{3} \mathrm{I}_{8}(\mathrm{DMSO})_{2}$ [17]. Then, they suggested that this intermediate phase was a key point to form high-quality perovskite layer [18]. After that, Bai et al. obtained a pure $\mathrm{MA}_{2} \mathrm{~Pb}_{3} \mathrm{I}_{8}(\mathrm{DMSO})_{2}$ intermediate phase by regulating the ratio of $\mathrm{DMSO}: \mathrm{PbI}_{2}$ in the perovskite precursor [19].

In order to maintain a superb performance of PSCs, the spin-coating process presented in the above works were all carried out under rigorous conditions in glove boxes with a small amount of oxygen and water, because the organic components in the perovskite structure is easily dissolved by moisture. This will undoubtedly increase the cost of manufacturing, and place restrictions on the eventual industrialization of PSCs. Therefore, fabricating perovskite films in ambient air is very important for technology's commercialization. Due to the existence of moisture, the dynamical process of perovskite growth in ambient air might be quite different from that in glove boxes. Several issues on high quality perovskite fabrication in air need to be clarified, such as what the role of intermediate phase is, and what the effect of moisture, anti-solvent and precursor solution on the intermediate phase is. There are still quite few reports on this discussion. Besides, there is a lack of understanding of the intermediate phase contained both $\mathrm{MA}^{+}$and $\mathrm{FA}^{+}$although perovskite of mixed cation is widely used for compatible high efficiency and durability of PSCs.

Here, the effects of precursor solution, anti-solvent, and moisture on the formation of intermediate phase were investigated and the mechanism was discussed in air condition. By simply mixing solvent (DMSO/DMF $=5: 0,4: 1,3: 2,2: 3$ ) volume ratio of precursor solution, the $\left(\mathrm{FA}_{0.2} \mathrm{MA}_{1.8}\right) \mathrm{Pb}_{3} \mathrm{X}_{8}(\mathrm{DMSO})_{2} /$ perovskite phase and $\left(\mathrm{FA}_{0.2} \mathrm{MA}_{1.8}\right) \mathrm{Pb}_{3} \mathrm{X}_{8}(\mathrm{DMSO} \cdot \mathrm{DMF})$ intermediate phase were acquired. In addition, the proper quantity of ethyl acetate $\left(\mathrm{C}_{4} \mathrm{H}_{8} \mathrm{O}_{2} \mathrm{EA}\right)$ is also a key to obtain pure intermediate phase. Therefore, the best PCE of a device is $16.24 \%$, and an average PCE is $15.53 \%$ by annealing pure $\left(\mathrm{FA}_{0.2} \mathrm{MA}_{1.8}\right) \mathrm{Pb}_{3} \mathrm{X}_{8}$ (DMSO-DMF) intermediate film. The steady-state efficiency of the device is $15.38 \%$ under continuous illumination, almost $86 \%$ of its initial PCE was preserved after 30 days in air conditions. At the same humidity, an active area of $100 \mathrm{~mm}^{2}$ device was fabricated with a PCE of $11.11 \%$ and showed a small hysteresis between the reverse and forward. All the process of spin-coating was done in the ambient air (RH20-30\%).

\section{Materials and Methods}

\subsection{Materials}

Materials used in our work include titanium (IV) isopropoxide (99.999\%, Alfa Aesar, Shanghai, China) and $\mathrm{PbI}_{2}$ (99\% Sigma-Aldrich, St. Louis, MO, USA). $\mathrm{CH}_{3} \mathrm{NH}_{3} \mathrm{I}$ (MAI, 99.5\%, 4 times purification), $\mathrm{CH}_{3} \mathrm{NH}_{3} \mathrm{Cl}$ (MACl, 99.5\%, 4 times purification), $\mathrm{CH}_{3}\left(\mathrm{NH}_{2}\right)_{2} \mathrm{I}$ (FAI, 99.5\%, 4 times purification), 2,2',7,7'-Tetrakis[N,N-di(4-methoxyphenyl)amino]-9,9'-spirobifluorene (Spiro-OMeTAD, 99.5\%), $\mathrm{TiO}_{2}$ paste (Dyesol-30NRD), Lithium bis(trifluoromethanesulfonyl)imide (Li-TFSI, 99\%),Tris(2-(1H-pyrazol-1-yl)-4-tert-butylpyridine)-cobalt(III)Tris(bis(trifluoromethylsulfonyl) imide)) (FK209, 99\%), and 4-tertbutylpyridine (TBP, 96\%) were obtained from Xi'an Polymer Light Technology Crop. (Xi'an, China). The solvent and anti-solvent, including N,N-Dimethylformamide (DMF, 99.5\%), Dimethyl sulfoxide (DMSO, 99.8\%), methyl acetate (MA, 99.95\%), ethyl acetate (EA, 99.95\%) and chlorobenzene (CB, 99.95\%) were obtained from Aladdin corporation (Shanghai, China). 


\subsection{Device Fabrication}

The device of PSCs was fabricated with the following structure: $\mathrm{FTO} / \mathrm{C}-\mathrm{TiO}_{2} / \mathrm{M}-\mathrm{TiO}_{2}$ /perovskite/Spiro-OMeTAD/Ag. FTO glass substrates were cleaned in acetone, isopropanol, ethanol, and deionized water for $15 \mathrm{~min}$ by ultrasonic cleaner and then the clean substrates were dried in air. Plasma cleaning was further done to treat the substrate at the $40 \mathrm{~W}$ for $30 \mathrm{~s}$. The $8 \mu \mathrm{L}$ concentrated hydrochloric acid and $40 \mu \mathrm{L}$ titanium(IV) isopropoxide were added in $1 \mathrm{~mL}$ ethanol to synthetize compact $\mathrm{TiO}_{2}\left(\mathrm{C}-\mathrm{TiO}_{2}\right)$ precursor solution, then spin-coated at $3000 \mathrm{rpm}$ for $30 \mathrm{~s}$ on FTO substrates and immediately annealed at $150{ }^{\circ} \mathrm{C}$ for $15 \mathrm{~min}$ on a hot plate. The same process was repeated twice and annealed at $500{ }^{\circ} \mathrm{C}$ for $30 \mathrm{~min}$ to obtain $\mathrm{C}-\mathrm{TiO}_{2}$ layer. After that, the coated substrates were immersed into a $40 \mathrm{mM} \mathrm{TiCl}_{4}$ aqueous solution at $70{ }^{\circ} \mathrm{C}$ for $30 \mathrm{~min}$ and heat-treated at $500{ }^{\circ} \mathrm{C}$ for $30 \mathrm{~min}$. Mesoporous $\mathrm{TiO}_{2}\left(\mathrm{M}-\mathrm{TiO}_{2}\right)$ precursor was prepared by blending $\mathrm{TiO}_{2}$ paste with ethanol (weight ratio =1:4). After stirring for $12 \mathrm{~h}$ at room temperature, it was then spin-coated at $5000 \mathrm{rpm}$ for $45 \mathrm{~s}$ followed by annealing at $80{ }^{\circ} \mathrm{C}$ for $40 \mathrm{~min}$ and sintered at $500{ }^{\circ} \mathrm{C}$ for $30 \mathrm{~min}$. $1.3 \mathrm{M}$ perovskite precursor solution was prepared by mixing of $\mathrm{PbI}_{2}, \mathrm{MAI}, \mathrm{FAI}$, and $\mathrm{MACl}$ $($ molar ratio $=1: 0.8: 0.1: 0.1)$ in co-solvent $\left(\mathrm{V}_{\mathrm{DMSO}} \mathrm{V}_{\mathrm{DMF}}=5: 0,4: 1,2: 3,3: 2\right)$. Then, perovskite solutions were successively spin-coated on the substrates at $1000 \mathrm{rpm}$ for $10 \mathrm{~s}$ and $5000 \mathrm{rpm}$ for $30 \mathrm{~s}$. $100 \mu \mathrm{L}$ of ethyl acetate was dropped in $10 \mathrm{~s}$ at $5000 \mathrm{rpm}$ and was annealed at $100{ }^{\circ} \mathrm{C}$ for $40 \mathrm{~min}$. The $91 \mathrm{mg}$ of Spiro-OMeTAD with additives were dissolved in $1 \mathrm{~mL}$ chlorobenzene to prepare hole transport layer (HTL) solution. The additives include $21 \mu \mathrm{L}$ of Li-TFSI (520 mg in $1 \mathrm{~mL}$ of acetonitrile), $16 \mu \mathrm{L}$ of FK209 (375 mg in $1 \mathrm{~mL}$ of acetonitrile), and $36 \mu \mathrm{L}$ of TBP. The HTL was prepared by spin-coating the solution at $4000 \mathrm{rpm}$ for 20s on perovskite film. Finally, there was the deposition of the $100 \mathrm{~nm}$ thick Ag electrode by thermal evaporation in a high vacuum $\left(5 \times 10^{4} \mathrm{~Pa}\right)$. All the processes of spin-coating was done in ambient air (RH20-30\%).

\subsection{Film and Device Characterization}

J-V curves of the PSCs were taken using a Keithley 2400 source measure unit under simulated solar illumination of $100 \mathrm{~mW} \mathrm{~cm}^{-2}$ (AM 1.5G) in the air. The reverse scan is from $1.4-0.2 \mathrm{~V}$ and forward scan is from -0.2 to $1.4 \mathrm{~V}$ with scan rate of $100 \mathrm{mV} / \mathrm{s}$. The FTIR spectra were recorded on Excalibur 3100 (varian, Palo Alto, CA, USA). X-ray diffraction (XRD) patterns were tested by X-ray diffractometer (Bruker, Karlsruhe, Germany) with $\mathrm{Cu}$ ka radiation. The surface and cross section morphological of the perovskite films and PSCs devices were recorded by the scanning electron microscope (SEM S-4800, HITACHI, Tokyo, Japan). Atomic force microscopy (AFM) of perovskite film was tested by the equipment of Bruker Dimension Icon. UV-vis absorption spectra of samples were measured by spectrophotometer (Cary 5000, Palo Alto, CA, USA). Steady-state photo-luminescence (PL) spectra and time resolved photoluminescence (TRPL) decay was measured by PL spectrometer (F900, Xianggan, Beijing, China) with an excitation wavelength of $510 \mathrm{~nm}$ and $375 \mathrm{~nm}$ respectively. The IPCE measurements were carried out by Zolix SCS10-X150-DZ system (Zolix, Beijing, China) with the DC mode.

\section{Results and Discussion}

The $\mathrm{PbI}_{2}, \mathrm{MAI}, \mathrm{FAI}$, and $\mathrm{MACl}$ were dissolved in co-solvent $\left(\mathrm{V}_{\mathrm{DMSO}} / \mathrm{V}_{\mathrm{DMF}}=5: 0,4: 1,3: 2,2: 3\right)$. The names of these precursor solutions correspond to ODMF, 1DMF, 2DMF, and 3DMF, respectively. Figure 1a shows the perovskite precursor solutions of different solvent volume ratio. The solutions color was transparent yellow which indicated the solutes had been completely dissolved after $6 \mathrm{~h}$ stirring. Figure 1b shows Fourier Transform Infrared (FTIR) transmittance spectra of different precursors. The spectra exhibited apparent shallowing of the peak at $3435 \mathrm{~cm}^{-1}$ with increasing DMF content, corresponding to the $\mathrm{O}-\mathrm{H}$ bond within the water molecule. That suggests absorption water in the solution, and as the amount of DMSO decreases, water is also decreasing, which is due to hydration of DMSO. 
(a)

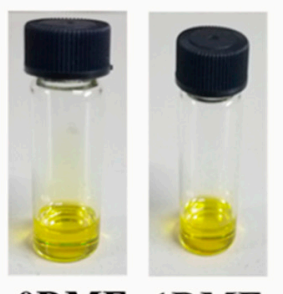

ODMF 1DMF

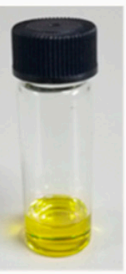

2DMF (b)

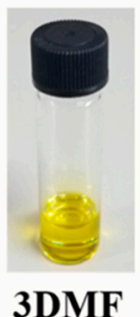

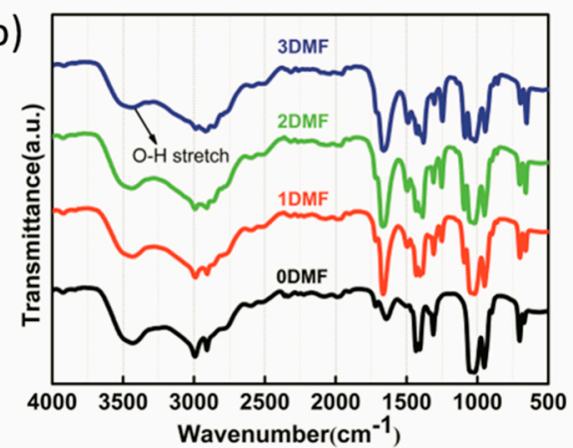

Figure 1. (a) Different perovskite precursor solution photos; (b) Fourier Transform Infrared (FTIR) transmittance spectra of precursor solutions.

Figure 2 shows the schematic fabrication of perovskite film. The prepared precursor was spin-coated on mesoporous $\mathrm{TiO}_{2}\left(\mathrm{M}-\mathrm{TiO}_{2}\right)$ by a one-step anti-solvent spin-coating processes at $1000 \mathrm{rpm}$ for $10 \mathrm{~s}$ and $5000 \mathrm{rpm}$ for $30 \mathrm{~s}$ successively [20]. During the spin-coating, EA was dripped on the spinning substrate in order to promote the formation of the intermediate phase [21]. In addition, EA was proved to avoid the air moisture into the intermediate phase [22,23]. Then, the intermediate film was transformed to pervoskite film after annealing at $100{ }^{\circ} \mathrm{C}$ for $40 \mathrm{~min}$.

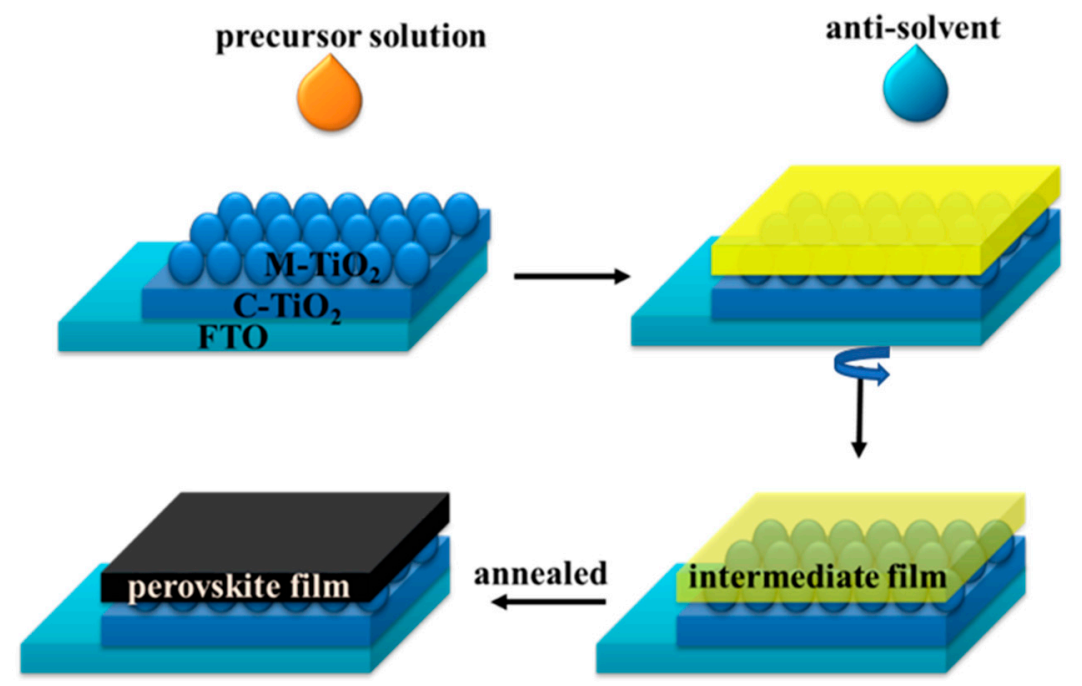

Figure 2. Schematic illustration of the perovskite film fabrication.

The intermediate film (Figure 3a) exhibited a clear difference in color. The color of film is light brown when fabricated from pure DMSO solution (ODMF case). As DMF was added in the precursors, the color of films changed from light brown to transparent, that indicated the different composition of intermediate films. Figure $3 \mathrm{~b}$ shows $\mathrm{X}$-ray diffraction $(\mathrm{XRD})$ patterns of different intermediate films deposited on FTO glass. The films showed identical peak positions compared to those previously reported of $\mathrm{MA}_{2} \mathrm{~Pb}_{3} \mathrm{I}_{8}(\mathrm{DMSO})_{2}$ intermediate phase [17] - the peaks at $6.53^{\circ}, 7.21^{\circ}$, and $9.19^{\circ}$ corresponded to (002), (021) and (022) planes of $\mathrm{MA}_{2} \mathrm{~Pb}_{3} \mathrm{I}_{8}(\mathrm{DMSO})_{2}$. It is noteworthy that different preferential crystal orientations of intermediate phase were manipulated by adjusting the concentration of DMF. In addition, the perovskite phase was observed in ODMF intermediate film, because the excessive water of solution owing to the strong hydration of DMSO provides greater bulk mobility to the MA and FA retained in the film, which accelerated the reaction with $\mathrm{PbI}_{2}$ to form perovskite phase during the spin-coating process [24]. By adding a small amount of DMF, the perovskite phase disappeared due to the reduced water of the solution, which has been 
identified by FTIR measurement. To further verify the contents of the intermediate phase, Attenuated Total Reflectance Fourier Transform Infrared (ATR-FTIR) spectra of intermediate films were measured. As shown in Figure 3c, vibrational bands observed at $3188 \mathrm{~cm}^{-1}$, which can be assigned to $\mathrm{NH}_{3}{ }^{+}$in $\mathrm{MAI}\left(\mathrm{CH}_{3} \mathrm{NH}_{3} \mathrm{I}\right)$ of intermediate phases [25]. A characteristic peak at $1714 \mathrm{~cm}^{-1}$ corresponded to stretching vibration of $\mathrm{C}=\mathrm{N}$ in FAI $\left[\mathrm{CH}\left(\mathrm{NH}_{2}\right)_{2} \mathrm{I}\right]$. The ATR-FTIR spectra of intermediate film based the hybrid FAMA cation and pure MA cation with 1DMF precursor solution is showed in Figure S1. The strong band at $1637 \mathrm{~cm}^{-1}$ is assigned to $C=O$ stretching vibration of DMF molecule and $1018 \mathrm{~cm}^{-1}$ is assigned to $S=O$ stretching vibration of DMSO molecule [26,27]. Thus, the composition of ODMF intermediate film was a mixture of nonstoichiometric $\left(\mathrm{FA}_{0.2} \mathrm{MA}_{1.8}\right) \mathrm{Pb}_{3} \mathrm{X}_{8}(\mathrm{DMSO})_{2}$ and perovskite phase. Additionally, the other films (1DMF, 2DMF, and 3DMF) are pure nonstoichiometric $\left(\mathrm{FA}_{0.2} \mathrm{MA}_{1.8}\right) \mathrm{Pb}_{3} \mathrm{X}_{8}(\mathrm{DMSO} \cdot \mathrm{DMF})$. The formation of intermediate phase can be explained as the reaction between Lewis acids and bases, where lone pair electrons on oxygen in DMSO and DMF donate to Lewis acid $\mathrm{Pb}^{2+}$ in $\mathrm{PbI}_{2}$ to form adducts through Van der Waals interactions. Iodide $\left(\mathrm{I}^{-}\right)$in MAI and FAI are also strong donors and thereby readily forms an adduct with $\mathrm{PbI}_{2}[16,28,29]$. Figure 4 shows the schematic crystal structure and composition of the intermediate phases (left), and then the perovskite phase (right) was formed due to the vaporization of solvent from the surface of the intermediate film after annealing.

(a)

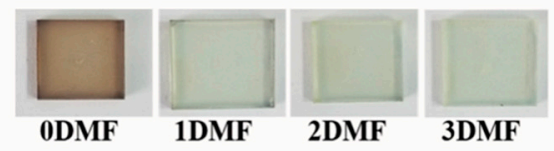

(b)

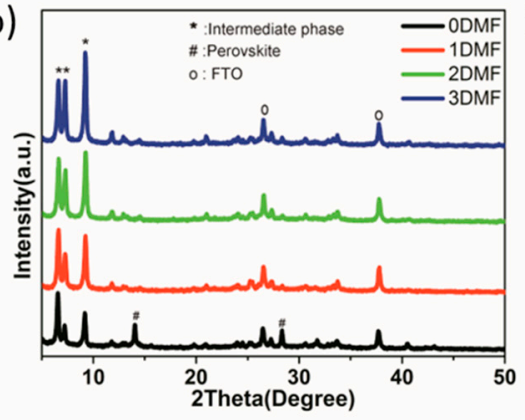

(c)

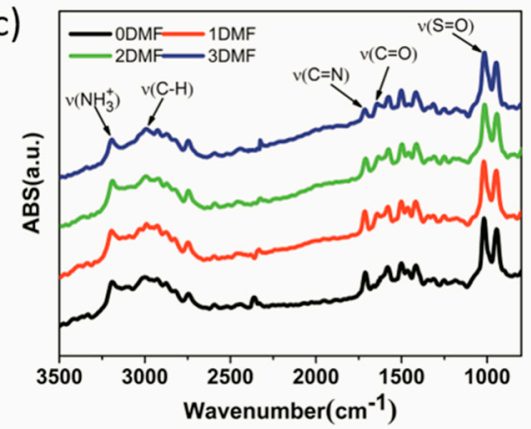

Figure 3. (a) The intermediate film photos of different precursors; (b) the X-ray diffraction (XRD) patterns and (c) Attenuated Total Reflectance Fourier Transform Infrared (ATR-FTIR) spectra of intermediate films.

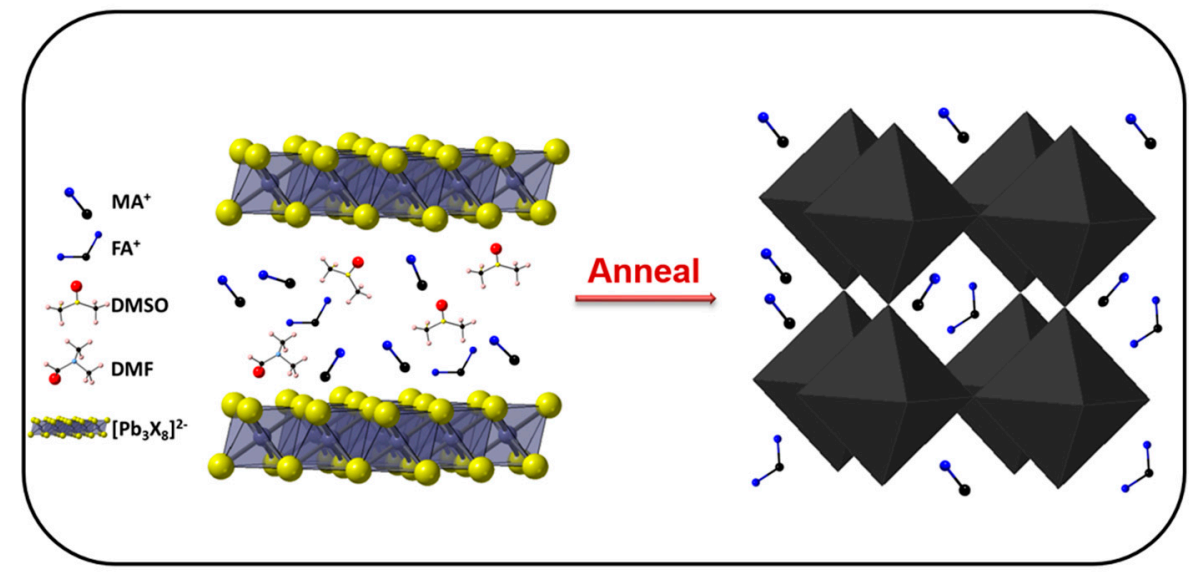

Figure 4. Schematic illustration of the intermediate phase (left) and perovskite phase (right). 
To further ascertain exactly how intermediate phase affects the surface morphology, crystallinity, and charge-carrier transport properties of the perovskite film, the annealed film was tested systematically. Figure 5 shows the scanning electron microscopy (SEM) images of perovskite films after annealing intermediate films. In the ODMF case (Figure 5a,e), many grain boundaries are observed and randomly distributed in the film owing to the presence of perovskite phase and $\left(\mathrm{FA}_{0.2} \mathrm{MA}_{1.8}\right) \mathrm{Pb}_{3} \mathrm{X}_{8}(\mathrm{DMSO})_{2}$ phase in intermediate films. The intermediate phase and perovskite phase have different growth directions that results in structural mismatch and is apt to produce more horizontal boundaries [19]. By adding a small amount of DMF (Figure 5b,f), the film was uniform, smooth, and showed almost no pinholes thanks to the pure intermediate phase before annealing. On further increasing the amount of DMF (Figure $5 c, d, g, h$ ), many pinholes appeared on the perovskite films although pure intermediate phase was also obtained in unannealed film. The rough film surface can be explained by the excess DMF evaporating more rapidly than DMSO during the annealing process [30], owing to the lower boiling point and weaker coordination ability with $\mathrm{PbI}_{2}$ [31]. This results revealed that the key of forming high quality perovskite film in air condition is following two aspects: Promoting the formation of the pure intermediate phase $\left(\mathrm{FA}_{0.2} \mathrm{MA}_{1.8}\right) \mathrm{Pb}_{3} \mathrm{X}_{8}(\mathrm{DMSO} \cdot \mathrm{DMF})$ without the perovskite phase, and controlling the rate of solvent evaporation.
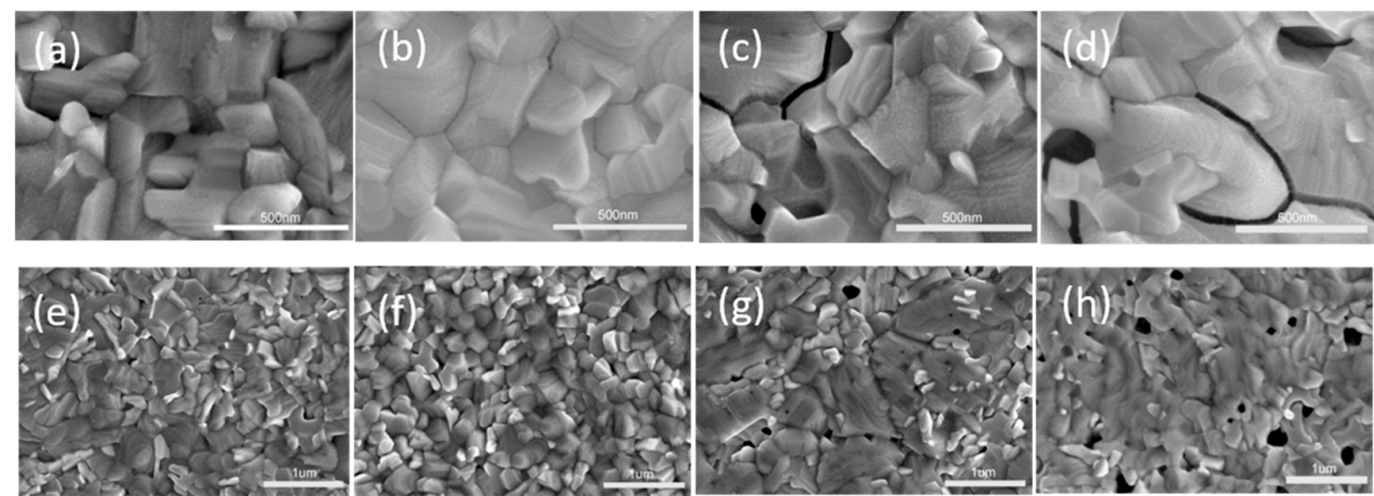

Figure 5. The SEM images of perovskite film by different precursors of ODMF (a,e); 1DMF (b,f); 2DMF (c,g); $3 \mathrm{DMF}(\mathbf{d}, \mathbf{h})$.

Figure 6 shows the atomic force microscopy (AFM) images of perovskite film. The root mean roughness values $(\mathrm{Rq})$ were measured as 17.9, 16.3, 18.5, and $19 \mathrm{~nm}$ for film surface prepared by precursors of ODMF, 1DMF, 2DMF, and 3DMF, respectively. The Rq of 1DMF sample was the smallest, which indicated a smooth surface of perovskite film. The corresponding 3D surface plot images (Figure 6e-f) apparently show the change of the surface roughness of perovskite films, which were in accordance with SEM images.

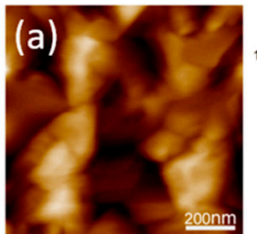

(e)

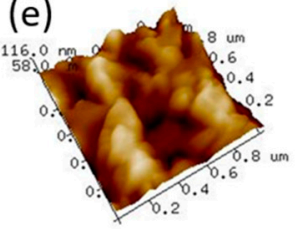

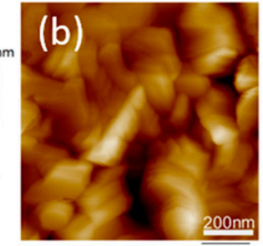

(f)

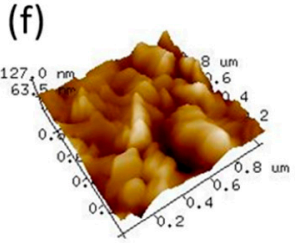

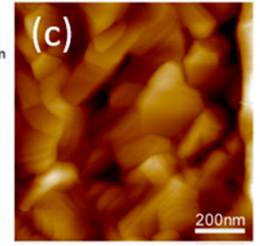

(g)

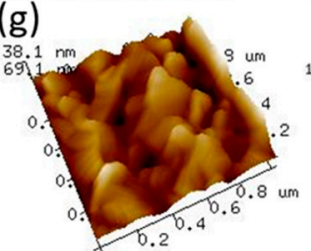

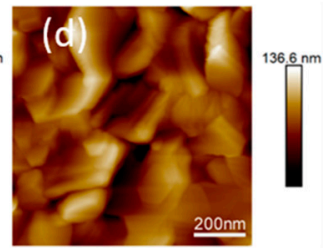

(h)

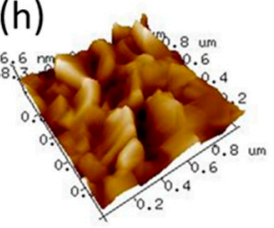

Figure 6. Atomic force microscopy (AFM) images of the perovskites film by different precursors (a,e) 0DMF, (b,f) 1DMF, (c,g) 2DMF, (d,h) 3DMF. 
Figure 7a shows XRD patterns of the perovskite film on quartz substrate. The intermediate phase was not observed in the XRD patterns of all annealed films. And three diffraction peaks at $14.28^{\circ}, 28.56^{\circ}$, and $31.99^{\circ}$ correspond to the (110), (220), and (310) planes of perovskite, respectively, confirming the entire intermediate phase was transformed into the perovskite phase [32]. In addition, the diffraction peak at $13.04^{\circ}$ is $\mathrm{PbI}_{2}$ phase. It was reported that residual $\mathrm{PbI}_{2}$ could passivate the defects and reduce recombination in the perovskite film, and further improve the device performance [33]. It is apparent that the 1DMF diffraction peak of (110) and (220) planes were obviously higher than other samples-this could indicate higher crystallization of perovskite film [34,35]. Therefore, the results clearly demonstrate that the perovskite crystal quality was controlled by composition of the intermediate film. Figure $7 \mathrm{~b}$ compares the UV-vis absorption spectra of the perovskite films on quartz substrate. The absorption edge of the four samples are the same. The ODMF film exhibits less absorbance intensity, with increases the DMF amount, the intensity of absorption augment observably, which is attributed to the high quality of perovskite film [36]. Surprisingly, absorption of the 2DMF and 3DMF samples are higher than 1DMF samples, the small increase in absorption could be explained the scattering effect of the rough surface due to large pinholes in the films.

(a)

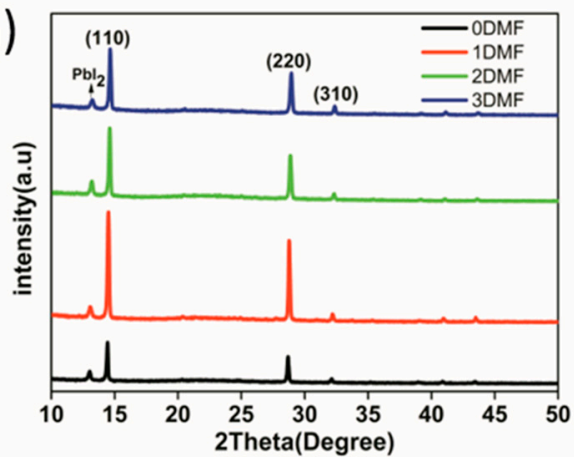

(c)

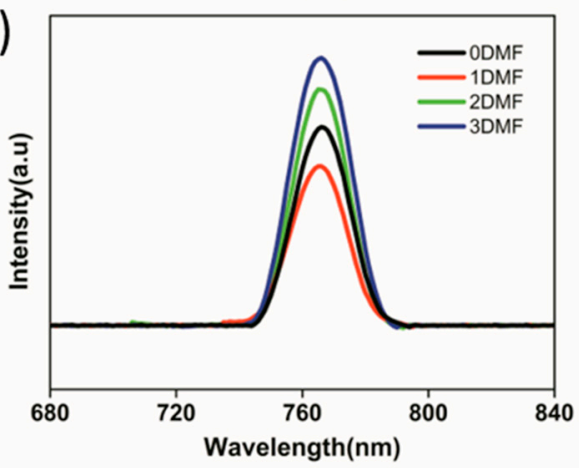

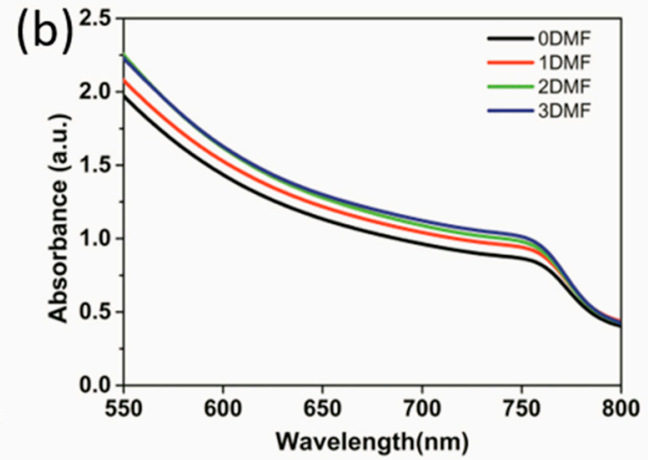

(d)

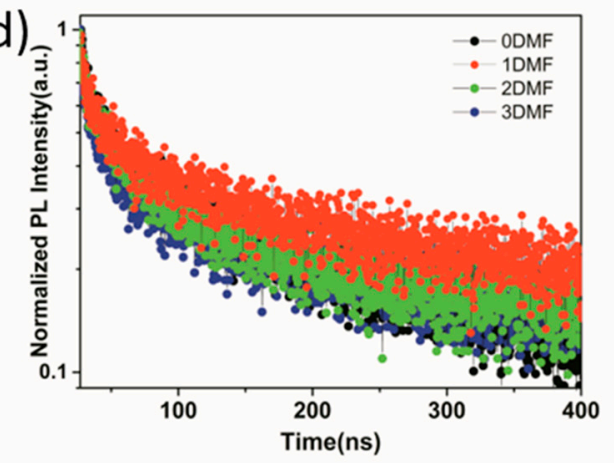

Figure 7. (a) XRD spectra of perovskite films on quartz by using different precursors; (b) UV-vis absorption spectra of perovskite films; (c) Steady-state photoluminescence (PL) spectra of different perovskite films on FTO/TiO2 (d) Normalized time-resolved PL (TRPL) spectra of the different perovskite films on glass.

The charge transport properties and charge recombination dynamics of perovskite films were further studied by steady-state photoluminescence (PL) and time-resolved PL (TRPL). Figure 7c shows room temperature PL spectra of perovskite films on $\mathrm{FTO} / \mathrm{TiO}_{2}$. The PL intensity of $1 \mathrm{DMF}$ film at $770 \mathrm{~nm}$ was weaker than the other films. That suggests the 1DMF film was better in charge transport and collection at the perovskite/ $\mathrm{TiO}_{2}$ interface. Figure $7 \mathrm{~d}$ shows normalized TRPL spectra of the perovskite films on glass. The TRPL decay curves could be fitted to a bi-exponential rate law:

$$
I(t)=A_{1} \exp \left(-t / \tau_{1}\right)+A_{2} \exp \left(-t / \tau_{2}\right)
$$


where $\tau_{1}$ is faster decay that determines carriers extracted through the glass/perovskite interface, and $\tau_{2}$ is slower decay which represents the lifetime of free charge carriers [37]. The 1DMF film exhibited the largest PL lifetime with $\tau_{2}$ of $346 \mathrm{~ns}$, that suggesting non-radiative recombination was effectively suppressed. These results indicated that the $1 \mathrm{DMF}$ films contained fewer traps and defects due to high-quality perovskite films [38-40].

To assess the impact of different precursors on device performance, the mesoporous PSCs based on the structure of $\mathrm{FTO} / \mathrm{C}-\mathrm{TiO}_{2} / \mathrm{M}-\mathrm{TiO}_{2} /$ Perovskite/Spiro-MeOTAD/Ag (Figure 8a) were constructed. Figure $8 \mathrm{~b}$ is cross-sectional SEM image of the PSCs. Figure $8 \mathrm{c}$ shows the J-V curves for PSCs based on four champion devices, and the corresponding photovoltaic parameters are listed in Table 1 . The device using pure DMSO precursors solution exhibited a PCE of $13.61 \%$, the open-circuit voltage (Voc) of $0.96 \mathrm{~V}$, the short-circuit photocurrent density (Jsc) of $22.7 \mathrm{~mA} / \mathrm{cm}^{2}$, and fill factor (FF) of $62.5 \%$. The best performance was obtained by a 1DMF device (a Voc $=1.03 \mathrm{~V}$, Jsc $=23.7 \mathrm{~mA} / \mathrm{cm}^{2}, \mathrm{FF}=66.5 \%$, and PCE $=16.24 \%$ ). The performance dropped for a $2 \mathrm{DMF}$ device (PCE of $14.38 \%$ ), and a 3DMF device $(12.61 \%)$. The obviously poor performance of ODMF device was on account of the low crystallinity of perovskite film and many horizontal boundaries on the film surface. The excellent performance of 1DMF device could be attributed to the enhanced crystallinity and surface morphology of peroverskite film and better interface contact, which restrained electron-hole recombination and promoted charge transport at interface. For 2DMF and 3DMF devices, the main cause of poor performance was pinholes in the film which lead to electrons in the $\mathrm{TiO}_{2}$ recombine with holes on spiro-OMeTAD [41]. External quantum efficiency (EQE) further confirmed the $\mathrm{J}_{\mathrm{SC}}$ results with the integrated $\mathrm{Jsc}$ of $22.05 \mathrm{~mA} / \mathrm{cm}^{2}$ of a champion 1DMF device, as displayed in Figure 8d. Figure 9 shows photovoltaic statistics for the PSCs by four precursors. The $1 \mathrm{DMF}$ devices exhibited photovoltaic parameters with little standard deviation, leading to average Voc of $1.01 \pm 0.02 \mathrm{~V}$, Jsc of $23.49 \pm 0.61 \mathrm{~mA} / \mathrm{cm}^{2}$, FF of $65.6 \pm 1.6 \%$, and PCE of 15.52 $\pm 0.72 \%$. The correlative data are showed in Table S1.

(a)

(b)

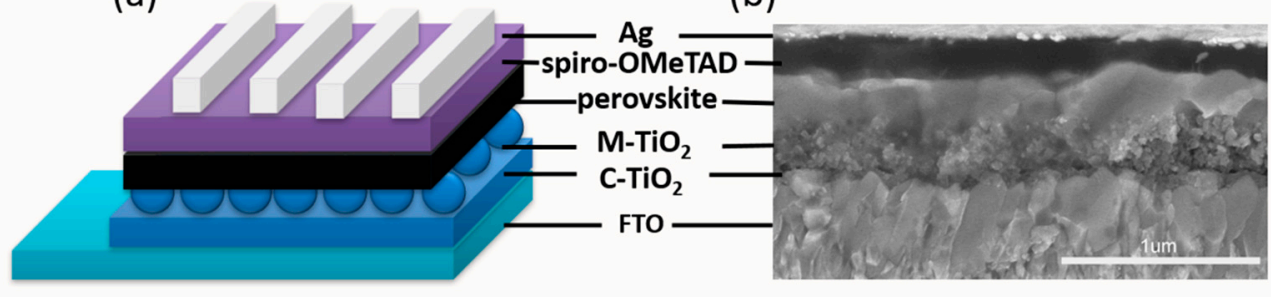

(c)

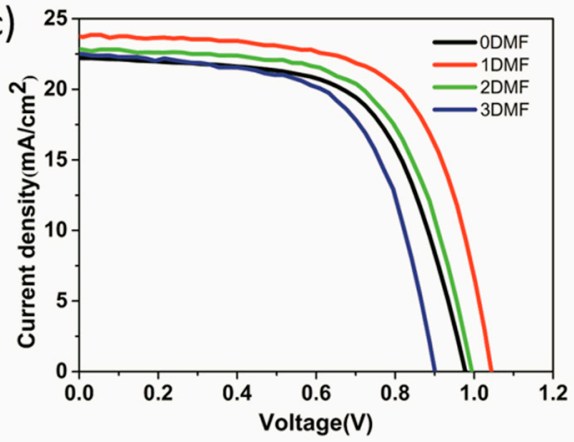

(d)

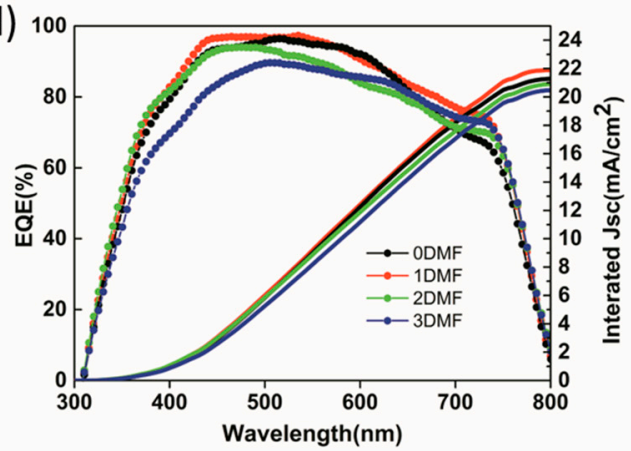

Figure 8 (a) Schematic device structure.

(b) Cross-sectional SEM image of $\mathrm{Ag} /$ Spiro-MeOTAD/Perovskite/M- $\mathrm{TiO}_{2} / \mathrm{C}-\mathrm{TiO}_{2} / \mathrm{FTO}$ device; (c) J-V curves of champion devices based four precursors; (d) the corresponding EQE curves. 
Table 1. Photovoltaic parameters of champion devices based on different precursor.

\begin{tabular}{ccccc}
\hline Precursor & Voc $(\mathbf{V})$ & Jsc $\left(\mathbf{m A} / \mathbf{c m}^{\mathbf{2}}\right)$ & FF (\%) & PCE (\%) \\
\hline 0DMF & 0.96 & 22.7 & 62.5 & 13.61 \\
1DMF & 1.03 & 23.7 & 66.5 & 16.24 \\
2DMF & 0.99 & 22.8 & 63.7 & 14.38 \\
3DMF & 0.90 & 22.5 & 62.3 & 12.61 \\
\hline
\end{tabular}

(a)

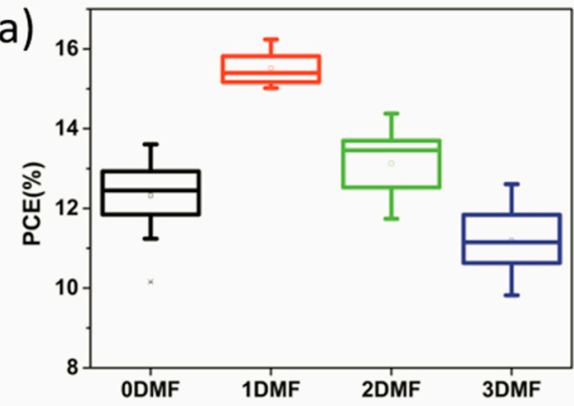

(c)

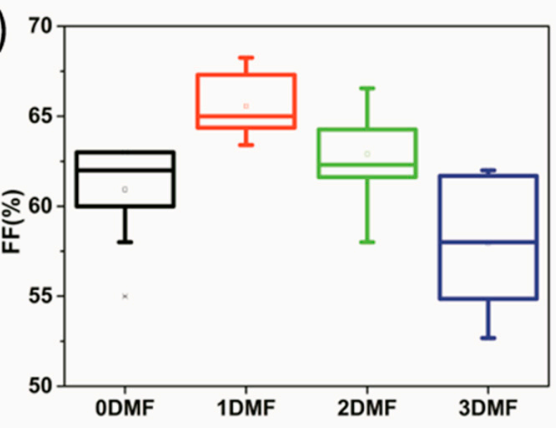

(b)

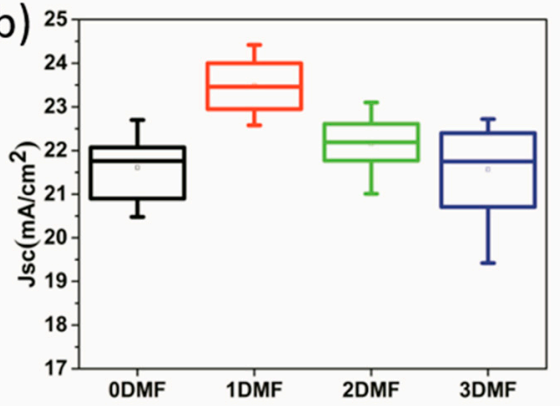

(d)

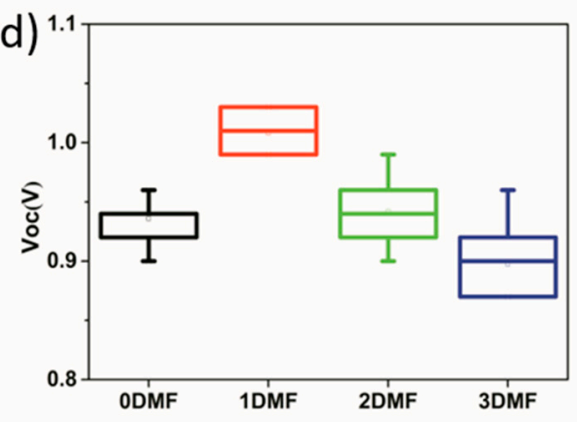

Figure 9. Photovoltaic statistics for the PSCs by four precursors. (a) PCE; (b) Jsc; (c) FF, and (d) Voc.

Figure 10a shows the stable output of current density and PCE of a 1DMF device under continuous illumination at a bias voltage of $0.8 \mathrm{~V}$. The 1DMF device works with an average PCE of $15.38 \%$. The long-term stability of the devices was tested, which were stored in ambient air (RH20-40\%) without sealing, as shown in Figure 10b. The 1DMF device exhibited the best stability among all the devices, with almost $86 \%$ of its initial PCE preserved after 30 days in air conditions which benefited from high-quality perovskite film. The surprised stability of the champion device in ambient air is mainly from the following aspects. First of all, the high crystallinity of the perovskite film deduced the probability of defect driven degradation and provided a basis for the device stability. In addition, the uniform film and compact interface prevented moisture into perovskite film, which further enhanced the humidity stability of device. Finally, the unencapsulated device was stored in dark air condition, which reduced the damage from light [42-45]. 
(a)

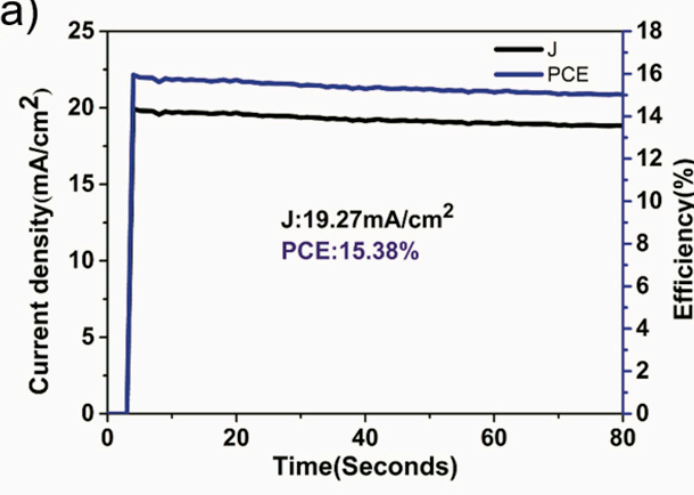

(b)

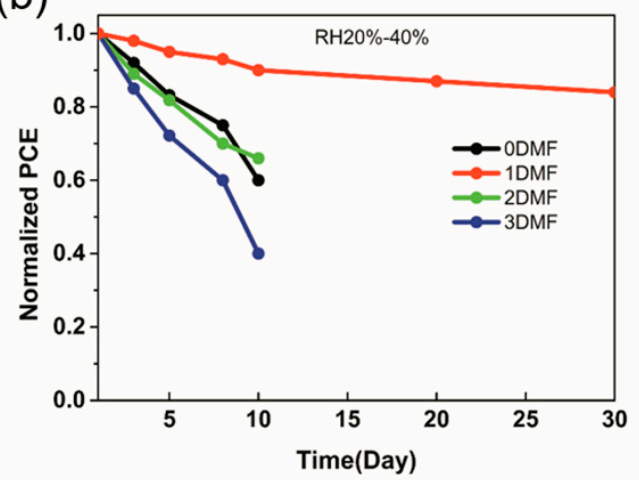

Figure 10. (a) Steady-state current density and PCE of 1DMF device under continuous illumination at maximum power point; (b) stability test for ODMF, 1DMF, 2DMF, and 3DMF PSCs in air condition (RH 20-40\%) without sealing.

To further examine the effect of the anti-solvent quantity to form intermediate film, Figure 11a shows the intermediate film photo of different ethyl acetate (EA) quantity $(50 \mu \mathrm{L}, 100 \mu \mathrm{L}, 300 \mu \mathrm{L}$, $500 \mu \mathrm{L}$ ) with $1 \mathrm{DMF}$ precursor solution. The intermediate film color changes from colorless to light brown and to deep brown with the increase of EA quality, indicating the perovskite phase component in intermediate film increased, which has been confirmed by XRD patterns (Figure 11b). This transformation is explained by the excess solvent washed by sufficient EA that resulted in fast crystallization of perovskite phases during the spin-coating process. Figure 11c shows the typical J-V curves of PSCs by dripping different quantity EA; the photovoltaic parameters are listed in Table 2. The corresponding photovoltaic statistics of the devices are shown in Table S2. The same volume $(100 \mu \mathrm{L}) \mathrm{CB}$ and methyl acetate (MA) were also used as anti-solvent in this work; the J-V curves and photovoltaic data are shown in Figure S2 and Table S3. It can be seen that both CB and MA devices show lower performance than the EA device, because the hydration of $\mathrm{CB}$ was poor and that of MA was too strong, while EA had proper hydration under this condition (RH 20-30\%).

(a)

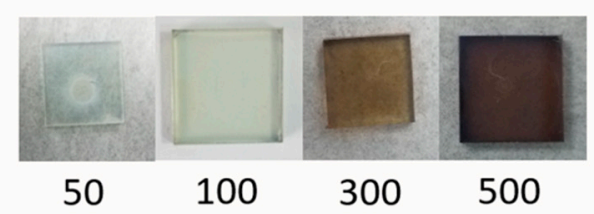

(b)

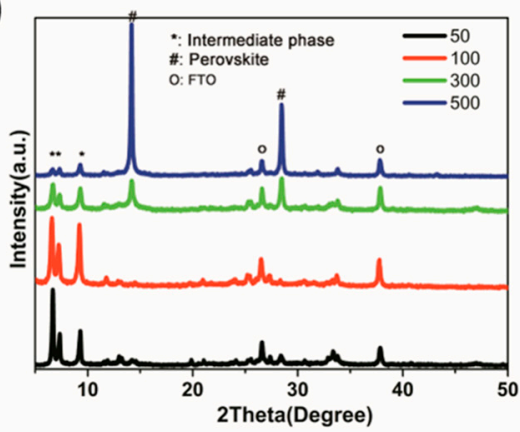

(c)

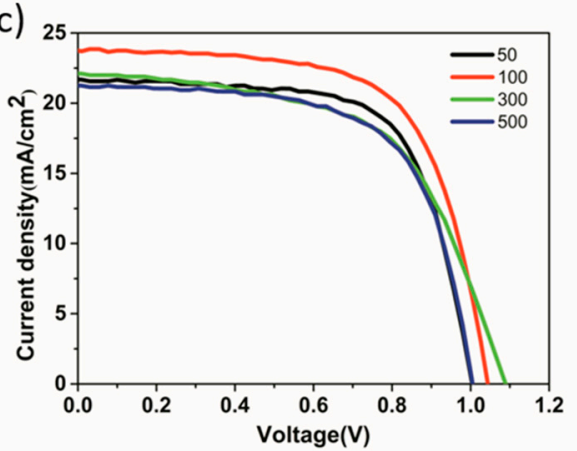

Figure 11. (a) The intermediate film photo by different quantity of $\mathrm{EA}(50 \mu \mathrm{L}, 100 \mu \mathrm{L}, 300 \mu \mathrm{L}, 500 \mu \mathrm{L})$; (b) XRD spectra of intermediate films; (c) J-V curves of devices. 
Table 2. Photovoltaic parameters of device by using different quantity of anti-solvent EA.

\begin{tabular}{ccccc}
\hline Anti-Solvent Volume $(\boldsymbol{\mu L})$ & Voc $(\mathrm{V})$ & Jsc $\left(\mathbf{m A} / \mathbf{c m}^{\mathbf{2}}\right)$ & FF (\%) & PCE (\%) \\
\hline 50 & 0.98 & 21.68 & 71.0 & 14.97 \\
100 & 1.03 & 23.70 & 66.5 & 16.24 \\
300 & 1.08 & 22.11 & 58.3 & 13.93 \\
500 & 1.01 & 21.26 & 64.3 & 13.81 \\
\hline
\end{tabular}

Finally, we fabricated a larger device with an active area of $100 \mathrm{~mm}^{2}$ in the same air condition; the J-V curves were shown in Figure 12a. The PCE of a device is $11.11 \%$ with negligible hysteresis when measured from reversing to forwarding. The inserted table is the corresponding photovoltaic parameters under forward and reverse scans, with the average Voc of $0.95 \mathrm{~V}$, Jsc of $22.475 \mathrm{~mA} / \mathrm{cm}^{2}$, FF of $51 \%$, and PCE of $10.81 \%$. Figure $12 \mathrm{~b}$ shows a stable output of current density and PCE of $100 \mathrm{~mm}^{2}$ device under one sun continuous illumination at maximum power point $(0.6 \mathrm{~V})$. The PSCs worked with the PCE of $11.04 \%$, which indicated good stability of power output.
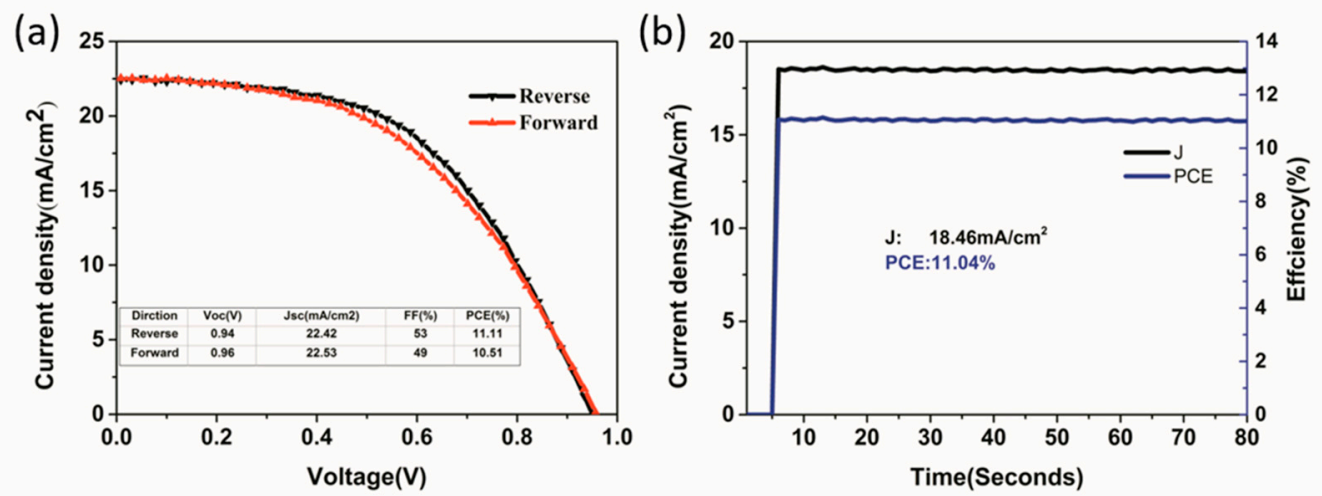

Figure 12. (a) Reverse and forward J-V curves of large area $\left(100 \mathrm{~mm}^{2}\right)$ device, and inserted table is the corresponding photovoltaic parameters under forward and reverse scans; (b) steady-state current density and efficiency of $100 \mathrm{~mm}^{2}$ device under continuous illumination at maximum power point $(0.6 \mathrm{~V})$.

\section{Conclusions}

In conclusion, we evaluated the effects of precursor solution, anti-solvent, and moisture on the formation of intermediate phase, and the mechanism was discussed about PSCs in air condition (RH $20-30 \%$ ). The excessive water of solution owing to the strong hydration of DMSO promotes the formation of perovskite phase in intermediate film, that results in poor quality perovskite film after annealing. The pure intermediate phase $\left(\mathrm{FA}_{0.2} \mathrm{MA}_{1.8}\right) \mathrm{Pb}_{3} \mathrm{X}_{8}(\mathrm{DMSO} \cdot \mathrm{DMF})$ and appropriate rate of solvent evaporation are key to forming high-quality perovskite layer in air condition. In addition, $100 \mathrm{uL}$ of EA was appropriate quantity to obtain pure intermediate phase in this work. Eventually, the best device PCE of $16.24 \%$ was obtained owing to high-quality perovskite film, compact interface contacts, and excellent charge transport properties. Moreover, the long-term stability of device was impressive, retaining $86 \%$ of its original performance after 30 days in air condition (RH 20-40\%) without sealing. At the same humidity condition, the device of $100 \mathrm{~mm}^{2}$ active area was fabricated, with PCE of $11.11 \%$ with a small hysteresis. This work contributes to further understanding the function of solvent engineering and film-forming mechanism from intermediate phase to perovskite phase, and to give an orientation for PSCs production at the commercial level. 
Supplementary Materials: The following are available online at http://www.mdpi.com/2079-4991/9/7/915/s1. Figure S1: The ATR-FTIR spectra of hybrid FAMA cation and pure MA cation intermediate films, Table S1: The photovoltaic parameters of device fabraication by four precursors (0DMF,1DMF,2DMF and 3DMF), Table S2: The photovoltaic statistics of device by using different quantity of EA. Figure S2: The J-V curves of device by dripping chlorobenzene (CB) and methyl acetate (MA), Table S3: corresponding photovoltaic parameters.

Author Contributions: Conceptualization, L.S., H.H., J.D. and H.L.; Data curation, L.S., T.Z. and J.H.; Formal analysis, L.S. and J.D.; Funding acquisition, H.H.; Investigation, L.S., C.Z. and J.X.; Methodology, L.S., H.H., J.D. and J.H.; Project administration, H.H.; Software, L.S. and H.L.; Validation, J.X.; Visualization, L.S., and H.H.; Writing—original draft, L.S., H.H., T.Z. and J.H.; Writing—review \& editing, L.S., C.Z. and J.H.

Funding: This research was funded by the National Natural Science Foundation of China, grant number No. 21875223 and Fundamental Research Funds for the Central Universities, grant number No. 2652017163.

Conflicts of Interest: The authors declare no conflict of interest.

\section{References}

1. Kojima, A.; Teshima, K.; Shirai, Y.; Miyasaka, T. Organometal halide perovskites as visible-light sensitizers for photovoltaic cells. J. Am. Chem. Soc. 2009, 131, 6050-6051. [CrossRef] [PubMed]

2. NREL. Best Research-Cell Efficencies. Available online: https:/www.nrel.gov/pv/assets/pdfs/best-researchcell-efficiencies-190416.pdf (accessed on 24 June 2019).

3. Malinkiewicz, O.; Yella, A.; Lee, Y.H.; Espallargas, G.M.; Graetzel, M.; Nazeeruddin, M.K.; Bolink, H.J. Perovskite solar cells employing organic charge-transport layers. Nat. Photonics 2013, 8, 128. [CrossRef]

4. Stranks, S.D.; Eperon, G.E.; Grancini, G.; Menelaou, C.; Alcocer, M.J.P.; Leijtens, T.; Herz, L.M.; Petrozza, A.; Snaith, H.J. Electron-hole diffusion lengths exceeding 1 micrometer in an organometal trihalide perovskite absorber. Science 2013, 342, 341-344. [CrossRef] [PubMed]

5. Xing, G.; Mathews, N.; Sun, S.; Lim, S.S.; Lam, Y.M.; Grätzel, M.; Mhaisalkar, S.; Sum, T.C. Long-range balanced electron-and hole-transport lengths inorganic-inorganic CH3NH3PbI3. Science 2013, 342, 344-347. [CrossRef] [PubMed]

6. Burschka, J.; Pellet, N.; Moon, S.-J.; Humphry-Baker, R.; Gao, P.; Nazeeruddin, M.K.; Grätzel, M. Sequential deposition as a route to high-performance perovskite-sensitized solar cells. Nature 2013, 499, 316. [CrossRef] [PubMed]

7. Liu, M.; Johnston, M.B.; Snaith, H.J. Efficient planar heterojunction perovskite solar cells by vapour deposition. Nature 2013, 501, 395. [CrossRef]

8. Chen, Q.; Zhou, H.; Hong, Z.; Luo, S.; Duan, H.-S.; Wang, H.-H.; Liu, Y.; Li, G.; Yang, Y. Planar heterojunction perovskite solar cells via vapor-assisted solution process. J. Am. Chem. Soc. 2014, 136, 622-625. [CrossRef]

9. Manda, X.; Fuzhi, H.; Wenchao, H.; Yasmina, D.; Ye, Z.; Joanne, E.; Angus, G.W.; Udo, B.; Yi-Bing, C.; Leone, S. A fast deposition-crystallization procedure for highly efficient lead iodide perovskite thin-film solar cells. Angew. Chem. 2015, 53, 9898-9903.

10. Guo, Y.; Shoyama, K.; Sato, W.; Matsuo, Y.; Inoue, K.; Harano, K.; Liu, C.; Tanaka, H.; Nakamura, E. Chemical Pathways Connecting Lead(Ii) Iodide and Perovskite Via Polymeric Plumbate(Ii) Fiber. J. Am. Chem. Soc. 2015, 137, 15907-15914. [CrossRef]

11. Paek, S.; Schouwink, P.; Athanasopoulou, E.N.; Cho, K.T.; Grancini, G.; Lee, Y.; Zhang, Y.; Stellacci, F.; Nazeeruddin, M.K.; Gao, P. From nano- to micrometer scale: The role of antisolvent treatment on high performance perovskite solar cells. Chem. Mater. 2017, 29, 3490-3498. [CrossRef]

12. Lee, J.-W.; Kim, H.-S.; Park, N.-G. Lewis acid-base adduct approach for high efficiency perovskite solar cells. Acc. Chem. Res. 2016, 49, 311-319. [CrossRef] [PubMed]

13. Lv, M.; Dong, X.; Fang, X.; Lin, B.; Zhang, S.; Ding, J.; Yuan, N. A promising alternative solvent of perovskite to induce rapid crystallization for high-efficiency photovoltaic devices. RSC Adv. 2015, 5, 20521-20529. [CrossRef]

14. Gardner, K.L.; Tait, J.G.; Merckx, T.; Qiu, W.; Paetzold, U.W.; Kootstra, L.; Jaysankar, M.; Gehlhaar, R.; Cheyns, D.; Heremans, P.; et al. Nonhazardous solvent systems for processing perovskite photovoltaics. Adv. Energy Mater. 2016, 6, 1600386. [CrossRef]

15. Jeon, N.J.; Noh, J.H.; Kim, Y.C.; Yang, W.S.; Ryu, S.; Seok, S.I. Solvent engineering for high-performance inorganic-organic hybrid perovskite solar cells. Nat. Mater. 2014, 13, 897-903. [CrossRef] [PubMed] 
16. Ahn, N.; Son, D.Y.; Jang, I.H.; Kang, S.M.; Choi, M.; Park, N.G. Highly reproducible perovskite solar cells with average efficiency of $18.3 \%$ and best efficiency of $19.7 \%$ fabricated via lewis base adduct of lead(ii) iodide. J. Am. Chem. Soc. 2015, 137, 8696-8699. [CrossRef] [PubMed]

17. Rong, Y.; Tang, Z.; Zhao, Y.; Zhong, X.; Venkatesan, S.; Graham, H.; Patton, M.; Jing, Y.; Guloy, A.M.; Yao, Y. Solvent engineering towards controlled grain growth in perovskite planar heterojunction solar cells. Nanoscale 2015, 7, 10595-10599. [CrossRef]

18. Rong, Y.; Venkatesan, S.; Guo, R.; Wang, Y.; Bao, J.; Li, W.; Fan, Z.; Yao, Y. Critical kinetic control of non-stoichiometric intermediate phase transformation for efficient perovskite solar cells. Nanoscale 2016, 8 , 12892-12899. [CrossRef]

19. Bai, Y.; Xiao, S.; Hu, C.; Zhang, T.; Meng, X.; Li, Q.; Yang, Y.; Wong, K.S.; Chen, H.; Yang, S. A pure and stable intermediate phase is key to growing aligned and vertically monolithic perovskite crystals for efficient pin planar perovskite solar cells with high processibility and stability. Nano Energy 2017, 34, 58-68. [CrossRef]

20. Zhang, Y.; Grancini, G.; Feng, Y.; Asiri, A.M.; Nazeeruddin, M.K. Optimization of stable quasi-cubic faxma1-XPbI3 perovskite structure for solar cells with efficiency beyond 20\%. ACS Energy Lett. 2017, 2, 802-806. [CrossRef]

21. Yin, M.; Xie, F.; Chen, H.; Yang, X.; Ye, F.; Bi, E.; Wu, Y.; Cai, M.; Han, L. Annealing-free perovskite films by instant crystallization for efficient solar cells. J. Mater. Chem. A 2016, 4, 8548-8553. [CrossRef]

22. Troughton, J.; Hooper, K.; Watson, T.M. Humidity resistant fabrication of $\mathrm{ch}_{3} \mathrm{nh}_{3} \mathrm{pbi}_{3}$ perovskite solar cells and modules. Nano Energy 2017, 39, 60-68. [CrossRef]

23. Yang, F.; Kapil, G.; Zhang, P.; Hu, Z.; Kamarudin, M.A.; Ma, T.; Hayase, S. Dependence of acetate-based antisolvents for high humidity fabrication of $\mathrm{CH} 3 \mathrm{NH} 3 \mathrm{PbI} 3$ perovskite devices in ambient atmosphere. Acs Appl. Mater. Interfaces 2018, 10, 16482-16489. [CrossRef] [PubMed]

24. Eperon, G.E.; Habisreutinger, S.N.; Leijtens, T.; Bruijnaers, B.J.; van Franeker, J.J.; deQuilettes, D.W.; Pathak, S.; Sutton, R.J.; Grancini, G.; Ginger, D.S.; et al. The importance of moisture in hybrid lead halide perovskite thin film fabrication. ACS Nano 2015, 9, 9380-9393. [CrossRef] [PubMed]

25. Li, Y.; Wang, J.; Yuan, Y.; Dong, X.; Wang, P. Anti-solvent dependent device performance in ch3nh3pbi3 solar cells: The role of intermediate phase content in the as-prepared thin films. Sustain. Energy Fuels 2017, 1, 1041-1048. [CrossRef]

26. Shen, D.; Yu, X.; Cai, X.; Peng, M.; Ma, Y.; Su, X.; Xiao, L.; Zou, D. Understanding the solvent-assisted crystallization mechanism inherent in efficient organic-inorganic halide perovskite solar cells. J. Mater. Chem. A 2014, 2, 20454-20461. [CrossRef]

27. Bae, S.; Han, S.J.; Shin, T.J.; Jo, W.H. Two different mechanisms of CH3NH3PbI3 film formation in one-step deposition and its effect on photovoltaic properties of opv-type perovskite solar cells. J. Mater. Chem. A 2015, 3, 23964-23972. [CrossRef]

28. Cao, X.B.; Li, Y.H.; Fang, F.; Cui, X.; Yao, Y.W.; Wei, J.Q. High quality perovskite films fabricated from lewis acid-base adduct through molecular exchange. RSC Adv. 2016, 6, 70925-70931. [CrossRef]

29. Zhang, X.; Xiong, H.; Qi, J.; Hou, C.; Li, Y.; Zhang, Q.; Wang, H. Antisolvent-derived intermediate phases for low-temperature flexible perovskite solar cells. ACS Appl. Energy Mater. 2018, 1, 6477-6486. [CrossRef]

30. Lin, N.; Qiao, J.; Dong, H.; Ma, F.; Wang, L. Morphology-controlled CH3NH3PbI3 films by hexane-assisted one-step solution deposition for hybrid perovskite mesoscopic solar cells with high reproductivity. J. Mater. Chem. A 2015, 3, 22839-22845. [CrossRef]

31. Wu, Y.; Islam, A.; Yang, X.; Qin, C.; Liu, J.; Zhang, K.; Peng, W.; Han, L. Retarding the crystallization of PbI2 for highly reproducible planar-structured perovskite solar cells via sequential deposition. Energy Environ. Sci. 2014, 7, 2934-2938. [CrossRef]

32. Bai, Y.; Chen, H.; Xiao, S.; Xue, Q.; Zhang, T.; Zhu, Z.; Li, Q.; Hu, C.; Yang, Y.; Hu, Z.; et al. Effects of a molecular monolayer modification of nio nanocrystal layer surfaces on perovskite crystallization and interface contact toward faster hole extraction and higher photovoltaic performance. Adv. Funct. Mater. 2016, 26, 2950-2958. [CrossRef]

33. Jiang, Q.; Zhang, L.; Wang, H.; Yang, X.; Meng, J.; Liu, H.; Yin, Z.; Wu, J.; Zhang, X.; You, J. Enhanced electron extraction using $\mathrm{SnO} 2$ for high-efficiency planar-structure $\mathrm{HC}(\mathrm{NH} 2) 2 \mathrm{PbI} 3$-based perovskite solar cells. Nat. Energy 2016, 2, 16177. [CrossRef]

34. Jeong-Hyeok, I.; Chang-Ryul, L.; Jin-Wook, L.; Sang-Won, P.; Nam-Gyu, P. 6.5\% efficient perovskite quantum-dot-sensitized solar cell. Nanoscale 2011, 3, 4088-4093. 
35. Baikie, T.; Fang, Y.; Kadro, J.M.; Schreyer, M.; Wei, F.; Mhaisalkar, S.G.; Graetzel, M.; White, T.J. Synthesis and crystal chemistry of the hybrid perovskite $(\mathrm{CH} 3 \mathrm{NH} 3) \mathrm{PbI} 3$ for solid-state sensitised solar cell applications. J. Mater. Chem. A 2013, 1,5628-5641. [CrossRef]

36. Zhu, L.; Shi, J.; Lv, S.; Yang, Y.; Xin, X.; Xu, Y.; Xiao, J.; Wu, H.; Luo, Y.; Li, D. Temperature-assisted controlling morphology and charge transport property for highly efficient perovskite solar cells. Nano Energy 2015, 15, 540-548. [CrossRef]

37. Wu, J.; Xu, X.; Zhao, Y.; Shi, J.; Xu, Y.; Luo, Y.; Li, D.; Wu, H.; Meng, Q. Dmf as an additive in a two-step spin-coating method for $20 \%$ conversion efficiency in perovskite solar cells. ACS Appl. Mater. Interfaces 2017, 9, 26937-26947. [CrossRef] [PubMed]

38. Khadka, D.B.; Shirai, Y.; Yanagida, M.; Masuda, T.; Miyano, K. Enhancement in efficiency and optoelectronic quality of perovskite thin films annealed in macl vapor. Sustain. Energy Fuels 2017, 1, 755-766. [CrossRef]

39. Song, X.; Wang, W.; Sun, P.; Ma, W.; Chen, Z.-K. Additive to regulate the perovskite crystal film growth in planar heterojunction solar cells. Appl. Phys. Lett. 2015, 106, 033901. [CrossRef]

40. Zhu, Z.; Bai, Y.; Zhang, T.; Liu, Z.; Long, X.; Wei, Z.; Wang, Z.; Zhang, L.; Wang, J.; Yan, F.; et al. High-performance hole-extraction layer of sol-gel-processed nio nanocrystals for inverted planar perovskite solar cells. Angew. Chem. Int. Ed. 2014, 53, 12571-12575.

41. Leijtens, T.; Lauber, B.; Eperon, G.E.; Stranks, S.D.; Snaith, H.J. The importance of perovskite pore filling in organometal mixed halide sensitized TiO2-based solar cells. J. Phys. Chem. Lett. 2014, 5, 1096-1102. [CrossRef]

42. Yang, L.; Wang, J.; Leung, W.W. Lead iodide thin film crystallization control for high-performance and stable solution-processed perovskite solar cells. ACS Appl. Mater. Interfaces 2015, 7, 14614-14619. [CrossRef] [PubMed]

43. Leijtens, T.; Eperon, G.E.; Noel, N.K.; Habisreutinger, S.N.; Petrozza, A.; Snaith, H.J. Stability of metal halide perovskite solar cells. Adv. Energy Mater. 2015, 5, 1500963. [CrossRef]

44. Khadka, D.B.; Shirai, Y.; Yanagida, M.; Miyano, K. Degradation of encapsulated perovskite solar cells driven by deep trap states and interfacial deterioration. J. Mater. Chem. C 2018, 6, 162-170. [CrossRef]

45. Berhe, T.A.; Su, W.-N.; Chen, C.-H.; Pan, C.-J.; Cheng, J.-H.; Chen, H.-M.; Tsai, M.-C.; Chen, L.-Y.; Dubale, A.A.; Hwang, B.-J. Organometal halide perovskite solar cells: Degradation and stability. Energy Environ. Sci. 2016, 9, 323-356. [CrossRef] 